\title{
Application of genomic technologies to measure and monitor antibiotic resistance in animals
}

\author{
Jian-Qiang Su, ${ }^{1}$ Li Cui, ${ }^{1}$ Qing-Lin Chen, ${ }^{1}$ Xin-Li An, ${ }^{1}$ and Yong-Guan Zhu ${ }^{1,2}$

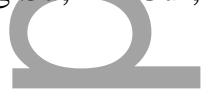 \\ ${ }^{1}$ Key Lab of Urban Environment and Health, Institute of Urban Environment, Chinese Academy of \\ Sciences, Xiamen, China. ${ }^{2}$ State Key Lab of Urban and Regional Ecology, Research Center for \\ Eco-Environmental Sciences, Chinese Academy of Sciences, Beijing, China
}

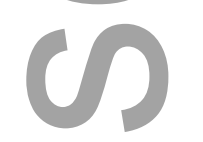

Address for correspondence: Yong-Guan Zhu, Key Lab of Urban Environment and Health, Institute of Urban Environment, Chinese Academy of Sciences, Xiamen, 361021, China. ygzhu@iue.ac.cn

Short title: Genomic technologies to investigate AR in animals

\begin{abstract}
Animal intestinal microbiota is one of the richest reservoirs of antibiotic-resistant bacteria and genes, contributing to the spread of antibiotic resistance in the environment and potentially into human pathogens. Both culture-based genomic technology and culture-independent metagenomics have been developed to investigate the abundance and diversity of antibiotic-resistance genes. The characteristics, strengths, limitations, and challenges of these genomic approaches are discussed in this review under the context of antibiotic resistance in animals. In addition, we discuss the advances in single-cell genomics and its potential for surveillance of antibiotic resistance in animals.
\end{abstract}

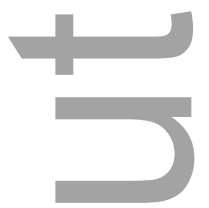

This is the author manuscript accepted for publication and has undergone full peer review but has not been through the copyediting, typesetting, pagination and proofreading process, which may lead to differences between this version and the Version of Record. Please cite this article as doi: $\underline{10.1111 / \text { nyas. } 13296 .}$.

This article is protected by copyright. All rights reserved. 
Keywords: antibiotic resistance; animals; metagenomics, single-cell genomics

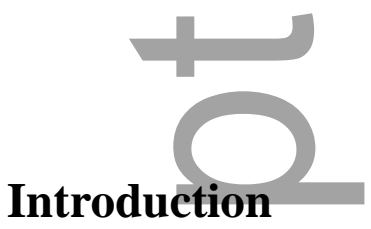

Since the introduction of sulfonamides and penicillin into medicine, ${ }^{1,2}$ antibiotics have contributed significantly to the control of bacterial infectious disease. ${ }^{3}$ However, the increasing emergence and spread of antibiotic resistance have hampered infection therapies by antibiotics, leading to numerous infectious death and huge costs of health care. ${ }^{4}$ Thus the World Health Organization (WHO) is developing a 5-year Global Antimicrobial Resistance Surveillance System (GLASS) to support the Global Action Plan on Antibiotic Resistance, ${ }^{5}$ with a major focus on antibiotic resistance in human pathogens. However, there are global concerns over the role of animal farms in the development and spread of antibiotic resistance among animals, environments, and humans. ${ }^{6,7}$

Antibiotic resistance is ancient and ubiquitous, but undergoing rapid evolution and dissemination in the modern environment. Antibiotic resistance genes (ARGs) are the genetic determinants of antibiotic resistance. A collection of all the ARGs is referred to as the antibiotic resistome, which includes intrinsic resistance genes, acquired resistance genes, proto-resistance genes, and silent resistance genes. ${ }^{2,-11}$ By using culture-based screening, quantitative polymerase chain reaction (qPCR), metagenomics, and functional metagenomics techniques, research efforts in the field of antibiotic resistomes have revealed the existence of diverse and abundant ARGs in various ecosystems, including humans, ${ }^{12}$ animals, ${ }^{13}$ bodies of water, ${ }^{14}$ soils, ${ }^{15}$ and air, ${ }^{16}$ and even in extreme environments, such as glaciers, ${ }^{17}$ permafrost,${ }^{18}$ and deep-sea sediments. ${ }^{19}$ Imprudent use of antimicrobial drugs in both human health care and the livestock industry is one of the major driving forces for the spread of antibiotic resistance. ${ }^{1,18,20}$ More than 50\% of produced antibiotics have been administered in animal farms for preventing disease and promoting animal growth rather than treating infections ${ }^{21,22}$ resulting in the enrichment of ARGs in animal microbiomes. ${ }^{13,23}$ The intestinal bacteria of animals have been recognized as one particular important reservoir contributing to the widespread dissemination of ARGs in the environment. ${ }^{24-27}$ ARGs in animal feces, animal farm wastewater, and associated environments were detected with comparatively higher diversity and abundance. ${ }^{24,27-29}$ ARGs can spread from animals to humans via various pathways. ${ }^{30-32}$ Although the increase in the number, diversity, and resistant phenotypes of clinical pathogens directly threatens human and animal health, many of the ARGs were recruited from environmental non-pathogenic isolates, ${ }^{33-37}$ and 
exchange of ARGs was observed between environmental bacteria and human pathogens. ${ }^{36,38}$ These facts illustrate the potential human health risk posed by ARGs of animal origin and reinforce the urgent need for measuring and monitoring antibiotic resistance in animals. In recognition of the global threat posed by zoonotic pathogens, the Food and Agriculture Organization (FAO), the World Health Organization (WHO), and the World Organization for Animal Health (OIE) developed a tripartite collaboration framework to achieve One Health goals. ${ }^{39}$

Antibiotic resistance is the phenotype of a given microbial organism, often but not always conferred by a specific gene product. The definition of antibiotic resistance can be either species-centric, including a clinical definition based on minimum inhibitory concentration (MIC) break points and an epidemiological definition based on common epidemiological cut-off values for resistance, or gene-centric, based on comparison of MIC values between an ARG-harboring strain and its parental strain that did not contain this ARG. ${ }^{40}$ At the community level, antibiotic resistance of a given microbial community could be evaluated by microbial community-level growth and community tolerance. ${ }^{41}$ In the context of this review, we focus on the molecular genomic technologies that have been used or could be used for the characterization of ARGs in animals. Several reviews have described the diversity, ecology, and dispersion of ARGs in various environments, including animals, with both culture-based genomic and metagenomic approaches being discussed. ${ }^{1,2,6,742-50}$ The goal of this review is to complement previous reviews by extending the discussion of high-throughput quantitative PCR, microarray-based technology, and single-cell genomic technology applied in the investigation of ARGs in animals (Fig. 1).

\section{Culture-based genomic identification of ARGs}

Conventional culture-based techniques are classical methods to identify antibiotic resistance in the environment. Although culture-independent approaches have been used, the determination of break point values and resistance patterns is more frequently based on culture-dependent methods. ${ }^{51-53}$ The use of culture media with selective antibiotics allows the enumeration and isolation of specific bacterial groups. Antibiotic resistance of isolated strains can be measured using multiple tests, including broth and agar dilution assays for the estimation of MIC, the agar disk diffusion assay for the evaluation of the susceptibility of the bacterial isolate, and E-test assays. ${ }^{44}$ The use of microplates could increase the throughput of MIC determination of isolates. ARGs in isolated resistant strains can be either identified by PCR amplifying specific target genes or via annotation of genome sequences. 
In general, culture-dependent methods are laborious and time-consuming, and their major limitation stems from the small fraction of bacteria that can be cultivated from a complex environment. ${ }^{45}$ Nevertheless, pathogens and indicator bacteria are easily grown on selective media using standard procedures, which facilitate the profiling of both resistance phenotypes and genotypes of these bacteria $^{53-56}$ and further assessing their potential risks to human health. ${ }^{57,58}$

Although culture-independent molecular approaches are promising for exploring ARGs from natural environments, ${ }^{42}$ the data provided by cultured-based technologies are still valuable and should not be underestimated. First, culture-based methods can establish direct links between the resistance phenotype and the genotype, providing phenotypic information about complete and active genes (Fig. 1), which is not always the case when using molecular methods. such as silent genes that express phenotypic resistance when mobilized or mutated to associated regulatory elements. ${ }^{8,45}$ Multidrug-resistant bacteria are of particular clinical concern; ${ }^{54,55,59}$ the culture-based method is the most direct way to test multidrug resistance in bacterial isolates. ${ }^{44}$

Second, culture-based methods facilitate establishing links between ARGs and their bacterial hosts (Fig. 1) ${ }^{67}$ Identifying the hosts of ARGs is particularly important to determine the origin of ARGs and to assess the dispersion of ARGs between environmental bacteria and pathogens. ${ }^{68,69}$ However, it is challenging to determine ARG hosts in complex environmental microbial communities using metagenomic technology, which requires increased sequencing depth and greater efforts and expertise in bioinformatics. ${ }^{15,43}$

Third, whole-genome sequencing provides information about the arrangement of multiple ARGs and associated genes, such as metal-resistance genes. ${ }^{70}$ With the identification of multiple ARGs from a bacterial genome, both the multidrug resistance phenotype and genotype of a bacterial isolate can be characterized. ${ }^{11,60-66}$ More importantly, it enables the identification of ARGs that reside on mobile genetic elements (MGEs). MGE-associated ARGs could be exchanged among bacteria and pathogens via horizontal gene transfer (HGT), which contributes largely to the spread of ARGs. ${ }^{71-73}$ In addition, comparative genome analysis provides evidence about the determination of acquired resistance and intrinsic resistance and the hosts of these MGEs and associated ARGs. ${ }^{8,35,65,66,74-76}$

Finally, genome sequencing of numerous resistant isolates from humans and animals followed by phenotype characterization and comparative genomic analysis enables molecular epidemiological research on antibiotic resistance in human and animal populations, ${ }^{52,75,77,78}$ which will contribute to the determination of the sources of antibiotic resistance. ${ }^{79}$ Mather et al. proposed an ecological approach 
to assessing the epidemiology of antimicrobial resistance in Salmonella Typhimurium DT104 and found that animals and humans have distinguishable DT104 communities with different diversity and phenotypic resistance profiles. ${ }^{78}$ They further found distinguishable genotypic DT104 communities in human and animals, suggesting that other sources contribute to the diversity of the human resistance burden beyond the local animals. ${ }^{77}$ Such large-scale studies of the molecular epidemiology of antibiotic resistance could provide useful data for human health risk assessment. ${ }^{80}$ Martinez et al. determined that the ARGs residing on MGEs of clinical pathogens with validated resistant function to clinically important antibiotics exhibit the highest risk. ${ }^{40}$ With the aforementioned advantages, culture-based technologies provide critical information for understanding the phenotype, genotype, dissemination, and epidemiology of antibiotic resistance, especially in clinically important organisms.

Culture-independent molecular genomics technologies are efficient at detecting microorganisms that cannot be grown in the laboratory or that multiply very slowly or persist ${ }^{81}$ in specific compartments, enabling the capture of antibiotic resistance profiles at microbial community level. These technologies, which have been widely used to explore ARGs in nature and to address the dissemination of ARGs in different environments, ${ }^{1,2,6,7,42,43}$ will be discussed in the following sections.

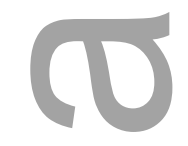

\section{Metagenomic exploration of ARGs}

Metagenomics is the study of all of the genome sequences of a community of organisms inhabiting an environmental sample. ${ }^{82,83}$ Metagenomic sequencing can provide a relatively unbiased view of not only the community structure (species richness and distribution) but also the functional (metabolic) potential of a community. ${ }^{83}$ In contrast to microarray-based and PCR-based methods, which bear the limitations of primer or probe design and selection, sequence-based metagenomics analysis is a powerful tool to explore the entire antibiotic resistome, including the occurrence of unforeseen ARGs in diverse environments, enabling the discovery of novel ARGs and novel resistance mechanisms. ${ }^{6,46}$

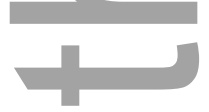

Metagenomic analysis of microbial communities from swine gut, ${ }^{23,84}$ cattle manure, ${ }^{29}$ chicken ceca, ${ }^{85}$ feline feces, ${ }^{86}$ and mice gut ${ }^{87}$ have revealed diverse and abundant ARGs and MGEs in animals. As a consequence, animal manure is considered as a hotspot for the spread of ARGs and MGEs to the environment. ${ }^{30,31}$ Antibiotic administration is one of the major factors influencing the abundance and 
diversity of ARGs in animals ${ }^{88}$ Looft et al. investigated the effects of in-feed sublethal antibiotics (ASP250 including chlortetracycline, sulfamethazine, and penicillin) on swine intestinal microbiome ARGs. ${ }^{23,84}$ Analysis of the metagenomes revealed that, despite a high background of ARGs in non-medicated swine, ARGs increased the abundance and diversity in the medicated swine microbiome after 14 days of antibiotic treatment; indirect selection of aminoglycoside $O$-phosphotransferases conferring resistance to antibiotics that were not applied was also observed. ${ }^{23}$ The segregation of ARGs is not solely due to the antibiotic usage in human and animals. ${ }^{89}$ Application of metals can also affect the ARGs profiles in animals by changing the microbial community or co-selecting metal-resistance genes and ARGs, resulting in co-resistance to both metals and antibiotics. ${ }^{90,91}$ Metagenomic analysis of the mouse gut microbiome showed that exposure to metals without antibiotics resulted in alteration of the diversity and functions of gut microbiota and increased the frequency of ARGs and MGEs. ${ }^{87}$

ARGs can be identified and annotated by homology search in the databases, such as the National Center for Biotechnology Information (NCBI) NR, the Antibiotic Resistance Gene Database (ARDB) ${ }^{92}$ and the Comprehensive Antibiotic Resistance Database (CARD). ${ }^{93}$ Sequence-based homology search has an advantage for automatic annotation of ARGs in huge metagenomes. Regardless of this, homology search will become a limitation when no significant similarity to any sequences in the ARGs database occurred, and, consequently, novel types of ARGs present in a sample might be missed. ${ }^{46,94}$ More importantly, the function of most of the ARGs annotated by homology search was not verified, which could inevitably produce false-positive annotation of ARGs, resulting in a vicious feedback loop when these false-positive ARGs are included in the ARGs database. ${ }^{40}$ Advances in bioinformatics, such as stringent similarity criteria, improved pipelines, and new algorithms for prediction of resistance phenotype from genotype, may improve the identification of true-positive ARGs. ${ }^{40,49,9}$

Functional metagenomic screening of ARGs can alternatively complement the limitation by providing direct evidence of resistance phenotypes when screening metagenomic libraries on selected media with target antibiotics (Fig. 1). Although functional metagenomics is relatively time consuming, laborious, and suffers from bias in molecular cloning and heterologous gene expression, ${ }^{48}$ it is powerful at identifying novel ARGs with validated function in the environment. ${ }^{38,96-100}$ Using this technology, a novel tetracycline resistance gene was identified and the association between tetracycline-resistance genes and MGEs as observed in the pig gut microbiome. ${ }^{101}$ Functional screening of metagenomic libraries coupled with Illumina sequencing of inserts increases the 
throughput of this technology and extends our knowledge of the ecology of the ARGs. ${ }^{15}$ By combining functional metagenomic and third-generation sequencing technology (PacBio sequencing), diverse ARGs were identified in dairy cow manure, including a novel clade of chloramphenicol acetyltransferases. $^{13}$

One particular challenge of metagenomics is to determine the host bacteria of identified ARGs (Fig. 1). The host of ARGs can be inferred indirectly by network analysis based on the co-occurrence pattern between ARGs and bacterial populations. ${ }^{28}$ Sequence analysis of the ARGs and flanking DNA provides direct information about the ARG host. The metagenome can be assembled, and the taxonomy affiliation of contigs containing annotated ARGs can be assigned. By using similarity-based methods, Ma et al. inferred the host of ARGs from diverse samples at different taxonomic levels, with the Escherichia genus exhibiting high correlation with multidrug-resistance genes. ${ }^{70}$ The taxonomic origin of ARGs can also be predicted using RAIphy, a composition-based classifier that uses the relative abundance index metric and an iterative classification method for taxonomic classification of DNA contigs with a large range of lengths assembled from metagenome data. ${ }^{102} \mathrm{By}$ using this algorithm, the source phyla of functional selected ARGs were predicted, with Proteobacteria and Actinobacteria being the most prevalent predicted phyla in soil. ${ }^{15}$ Although the phylogeny of ARGs was predicted at lower-resolution taxonomy (i.e., the phylum level), ${ }^{15}$ and the percentage of taxonomically identified contigs is relatively low at the genus level (i.e., less than $30 \%^{70}$ ), these studies successfully established the linkage between ARGs and their host, supporting further analysis of the origin of ARGs.

Another major challenge of metagenomics is to capture the genetic context of ARGs, which could not only aid in the taxonomic classification of annotated ARGs but also provide information on the co-occurrence of ARGs and ARGs with MGEs, which is of particular interest for assessing multidrug resistance and potential HGT. The detachment of genetic context largely is largely attributed to the detection limits at the current sequencing depth and cost and the challenge in efficient assembly of metagenomic sequences. ${ }^{6}$ This limitation could be ameliorated by decreasing sequencing costs and the development of bioinformatics. The third-generation sequencing can also help increase the efficiency for obtaining the genetic context of ARGs. With much longer reads than 454 pyrosequencing and Illumina sequencing, PacBio sequencing was used to sequence the large insert in the resistant clone from a cow manure metagenomic library, showing that the identified ARGs originated from diverse species and frequently clustered together, providing the genetic basis for the prediction of multidrug resistance. ${ }^{13}$ 
Co-occurrence of ARGs and MGEs can be investigated by directly sequencing the mobilome in the environment, which is defined as a collection of all mobile genetic elements in a metagenome. ${ }^{7,103}$ The transposon-aided capture (TRACA) system has been employed to isolate novel plasmids from the environmental metagenome, revealing the prevalence of ARGs and MGEs for HGT in microbial communities of sewage treatment plants. ${ }^{104}$ Gillings et al. found that the class 1 integron-integrase genes (intIl) recovered from clinical contexts have a homogenous and conserved DNA sequence and suggested that the relative abundance of these "clinical" intIl genes could serve as a genetic marker for anthropogenic influence owing to their emergence in human-dominated ecosystems and close links with ARGs. ${ }^{105}$ Sequencing the integron pools revealed a high proportion of integrons in hospital effluent, with distinct gene cassette diversity and gene cassette arrays. ${ }^{106}$ Sequencing a murine fecal phage population revealed that the phageome is a potential genetic reservoir of ARGs and that antibiotic treatment has resulted in the enrichment of ARGs for both administered drugs and unrelated antibiotics. ${ }^{107}$ Characterization of the mobilome in animals would provide insights into the mobile pools of ARGs that could be easily spread in the environment via HGT.

\section{Microarray-based detection of ARGs}

Microarray-based approaches are also high-throughput technologies for analysis of microbial phylogeny and functional genes in complex environments that enable simultaneous detection of up to thousands of well-designed biomarker genes. According to the types of targeted biomarkers, developed microarrays can be grouped into two major categories (i.e., phylogenetic and functional gene arrays ${ }^{108}$ ). Phylogenetic gene arrays were widely used for the characterization of microbial taxa in environments by targeting phylogenetic marker genes, including rRNA ${ }^{109}$ and gyrB genes. ${ }^{110}$ Various types of phylogenetic gene arrays have been developed targeting microbial communities in different habitats, including PhyloChip, which targets broad taxa; ${ }^{111,112}$ COMPOCHIP, which targets bacterial communities of different composts; ${ }^{113}$ and a microarray targeting human intestinal microbiota. ${ }^{114}$ In addition, microarrays based on gyrB have been developed for fine-level phylogenetic analysis of pathogenic species, including Escherichia coli, Shigella, Salmonella, Mycobacteria, and Legionella pneumophila. ${ }^{110,115-118}$

Functional gene arrays are designed on the basis of genes involved in the genomes of various bacterial species, ${ }^{119}$ pan-genomes (the complete set of genes of all strains in one bacterial species), ${ }^{120}$ and metagenomes ${ }^{121}$ for comparative genomic study, genotyping, or investigation of microbial 
functional composition and structure. ${ }^{122,123}$ Previously identified ARGs can be used for designing oligonucleotide probes that hybridize with genomic/metagenomic DNA for the detection of targeted ARGs in animals. Different types of ARG microarrays have been developed for detecting specific ARGs since at least $2003^{124,125}$ and have identified broad ranges of ARGs in pathogenic isolates ${ }^{126-129}$ and environmental DNA. ${ }^{130}$ These ARG microarrays have been used for genotyping and profiling ARGs in pathogens from livestock and poultry. ${ }^{131-136}$ Virulence factor genes are often included in microarrays with ARGs to achieve a fine-level characterization of both resistant and pathogenic genotypes in bacterial isolates of animal origins. ${ }^{126,131,132,137}$ A virulence factor gene-based microarray, PathoChip, containing 3715 probes targeting 13 virulence factors from 1397 microbial species (2336 strains), has been developed to investigate the pathogen population dynamics and pathogenic properties in the environment. ${ }^{138}$ ARGs are also targeted in other functional gene arrays. A microbial source-tracking microarray targeting pathogens, fecal indicator bacteria, source-tracking markers, and ARGs was designed for high-throughput detection of fecal contamination and pathogens in the environment and was tested against sewage and animal fecal samples. ${ }^{139}$ GeoChip, a functional gene array targeting genes involved in diverse biogeochemical processes, including virulence, metal resistance, and antibiotic resistance, ${ }^{122}$ has also been used to characterize the ARG profiles in environmental samples. ${ }^{130,140}$

As compared to metagenomic technology, which could provide new sequences, thus enabling the discovery of novel ARGs and resistant mechanisms, microarray-based technology requires existing sequences for probe design and does not provide new molecular information about ARGs or detect novel ARGs. Nevertheless, microarrays are characterized with high throughput, low detection limits, high reproducibility, and potential quantification, ${ }^{108}$ which is promising in rapid profiling of ARGs in the environment. The challenges of microarray-based technology are (1) the design of specific probes for ARGs that are highly homologous, incomplete, or both; (2) occasional large variations between or within technical replicates; (3) distinguishing true hybridization signals from nonspecific background noise; ${ }^{108}$ and (4) relatively lower sensitivity compared with a PCR-based assay.

\section{High-throughput quantitative PCR quantification of ARGs}

PCR-based technologies are highly sensitive and relatively rapid in detecting ARGs in either bacterial genomes or metagenomes. ${ }^{43}$ Traditional PCR is qualitative and can only provide evidence for the presence of ARGs in environments. In contrast, quantitative PCR (qPCR) provided both qualitative 
and quantitative information in addition to the benefits of PCR, thus providing a powerful means for rapid detection and enumeration of the abundance of ARGs, supporting comparative study on antibiotic resistance. Quantitative PCR has been successfully established to quantify ARGs and MGEs markers in environmental samples, including soil, water, and sewage sludge, ${ }^{105,141-143}$ and in animals $^{16,23,101,144-151}$ to investigate the distribution of ARGs and to assess the anthropogenic impacts on the ecology of ARGs.

Advances in genomic and metagenomic surveys have resulted in an increase in the number of ARGs in ARGs database, which facilitates the design of multiple specific primers targeting a variety of ARGs or MGEs markers. ${ }^{105,148,149,152-154}$ With conventional qPCR, Li et al. showed the potential spread of plasmid-mediated quinolone-resistance genes from swine feedlots by investigating the distribution of eight plasmid-mediated quinolone-resistance (PMQR) genes from swine feedlots and their surrounding environment. ${ }^{25}$ McEachran et al. detected several ARGs in the particulate matter from 10 beef cattle feed yards, raising concerns about the spread of ARGs via the air pathway. ${ }^{16}$ Our previous work demonstrated the prevalence of antibiotic residue and ARGs by quantifying 15 tetracycline-resistance genes in soils near nine swine feedlots. ${ }^{155}$ A total of 46 ARGs conferring resistance to several types of antibiotic were tracked by PCR and qPCR to evaluate the impact of manure fertilization on ARGs in soil and on vegetables at harvest. ${ }^{156}$ Despite the successful detection of ARGs by qPCR, conventional qPCR approaches suffer from low throughput design via 96/384-well microplates; therefore, numerous reactions are needed to detect and quantify diverse ARGs in environmental samples. Therefore, expanding the number of target ARGs and samples of interest will inevitably lead to dramatically increased cost and labor.

High-throughput qPCR (HT-qPCR), with the capability to perform thousands of nanoliter qPCR reactions, has been developed to simultaneously assess the expression and abundance of hundreds of genes, ${ }^{157-160}$ such as virulence and marker genes of pathogens. ${ }^{161,162}$ ARGs are diverse and abundant; a limited number of targeted ARGs is inadequate to represent the overall antibiotic resistance level in complex communities. For example, the tetracycline resistome comprises more than 40 resistance genes, including genes encoding efflux pumps, ribosomal protection proteins, mosaic elements, and inactivation enzymes. ${ }^{163}$ To address this limitation, HT-qPCR has been used to investigate the abundance and diversity of ARGs in environmental samples, including wastewater treatment plants, ${ }^{164}$ drinking water treatment plants and distribution systems, ${ }^{165}$ soils, ${ }^{166}$ compost,${ }^{167}$ rivers,${ }^{168}$ animals, and associated environments. ${ }^{23,24,169,170}$

This article is protected by copyright. All rights reserved. 
Although HT-qPCR is promising for rapid detection and quantification of hundreds of ARGs, similar to microarray-based technologies, the major limitation of HT-qPCR is that it depends on the ARG sequences in a database for primer design, and thus is unable to detect unknown distantly related ARGs in the environment. ${ }^{6}$ One major challenge of HT-qPCR is primer design and optimization for amplification conditions for each ARG, since the amplification reactions and thermal cycles are uniform throughout the assay. ${ }^{43}$ In addition, the detection limit of HT-qPCR is relatively higher due to the smaller reaction volume at nanoliter level rather than microliter level for conventional qPCR.

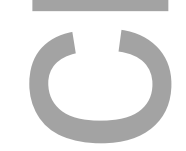

\section{Single-cell genomic technology}

Microbial genomes among a population of cells within an ecosystem are highly heterogeneous and far beyond what bulk approaches, such as metagenomics and HT-qPCR, can resolve. ${ }^{171}$ Recognition of cellular heterogeneity is very important considering that biological processes can be driven by individual cells with dynamic genomic variation. For example, heteroresistance within a clonal bacterial population under antibiotic stress is observed in a wide range of microbes and accounts for treatment failure; however, the exact genetic mechanism and its roles in adapting to antibiotic resistance remains obscure at the single-cell level. ${ }^{172,173}$ Single-cell sequencing aims to understand genomics at the single-cell level by dissecting the contribution of individual cells. ${ }^{171,174}$

Single-cell genomics can be used to identify and assemble the genomes of uncultivated bacteria or viruses (microbial dark matter) directly from environmental or clinical specimens (Fig. 1), enabling identification of vast numbers of novel genes encoding specific functions or metabolic pathways from microorganisms of interest that lack available sequence in the database. ${ }^{174}$ The captured genome can be further applied in a wide range of contexts, such as screening and enhancing biofuel production by bacteria, ${ }^{175}$ obtaining therapeutics from environmental bacteria, ${ }^{176}$ promoting the development of culture methods by correlating genome with the nutritional needs and metabolic processes of the organism, ${ }^{174}$ and facilitating design of a fluorescence in situ hybridization (FISH) probe for analyzing a microbial community and high-throughput screening of a microorganism of interest. ${ }^{177}$ Single-cell sequencing can also be combined and cross-validated with metagenomic methods to investigate shifts in microbial community structure by providing genetic linkage within individual cells and the overall genome of a community. ${ }^{178}$ 
There are technical challenges involved in obtaining high-quality single-cell genomes. ${ }^{171}$ Efficient physical isolation and collection of individual cells are the first steps in single-cell genomics. Approaches for isolating single cells have advanced from low-throughput manual operations to high-throughput ones that are more automatic. The low-throughput methods include micropipetting, ${ }^{179}$ nanoliter microwell dilution, ${ }^{180}$ optical tweezers, ${ }^{181}$ and laser ejection. ${ }^{182}$ The high-throughput methods mainly include flow cytometry and microfluidic devices combined with droplet or micromechanical valves or both. ${ }^{183-187}$ The combination with other techniques, such as fluorescence and Raman spectroscopy, can improve efficiency by screening cells of interest or biological importance. ${ }^{182,188-191}$ Whole-genome amplification (WGA) of single cells with acceptable bias and sufficient content for downstream analysis is another critical challenge in obtaining single-cell genomes. Multiple displacement amplification (MDA) is the most commonly used approach for WGA. Finally, single-cell genomics requires cost-effective sequencing, related bioinformatics, and appropriate data interpretation. ${ }^{171}$

Regardless of these challenges, single-cell genomics has competitive advantages in monitoring antibiotic resistance. Theoretically, emergence of antibiotic resistance in a single cell could allow the resistant strain to survive, proliferate, and eventually outcompete others under the selective pressure of antibiotics. 80,192 The frequency of resistance mutation and HGT could be very low in the environment (e.g., $10^{-8}$ for resistance mutation ${ }^{193}$ and $10^{-5}$ for HGT $^{194,195}$ ); tracking these rare events could be laborious using conventional culture methods. However, a single-cell genomic approach could be employed to sensitively and quantitatively detect these rare events (Fig. 1). The compartmentalization of single microbes ensures proliferation of both slow-growing and fast-growing bacteria without competition (Fig. 1) and thus produces diverse resistant phenotypes that might be missed via bulk culture. An agarose droplet-based microfluidic emulsion PCR was established with the ability to detect a single pathogenic E. coli $\mathrm{O} 157: \mathrm{H} 7$ cell in a high background of 100,000 excess normal K12 cells. ${ }^{185}$ By using a novel microfluidic-based picodroplet platform, fusidic acid-resistant strains could be screened and isolated in a high-throughput manner at an estimated frequency of resistance at $10^{-8}$; further sequence analysis of fus A detected novel single-nucleotide polymorphisms of fusA in isolated mutants. ${ }^{196}$ Single-cell genomics can also help reveal the genomic mechanisms of heteroresistance and lend insight into the changes of bacterial metabolism under selection pressure. ${ }^{172,197,198}$

Single-cell genomics have advanced rapidly in recent years and have resulted in new discoveries that bulk genomics cannot achieve. Application of single-cell genomics to address antibiotic 
resistance in animals has been rarely reported to date, but holds promising potential. For example, single-cell whole-genome sequencing of a large majority of uncultivated resistant bacteria facilitates the identification of new genes encoding novel resistance mechanisms and pathways. Bacterial species of interest in a given environment could be labeled, sorted out, and sequenced for comparative genomic analysis. Isolated single cells could be incubated in various antibiotics with different concentrations for determination of resistance, and the obtained resistance phenotypes could be sequenced for elucidation of their resistance mechanisms. The correlation of phenotype with genotype at the single-cell level will unambiguously link the resistance genes with its host bacteria, reaching a much higher resolution compared with community-level analysis of resistance genes and microbial structure. In addition, single-cell stable-isotope probing (SIP) coupled with Raman spectroscopy can directly reveal bacteria that subsist on antibiotics. ${ }^{199}$

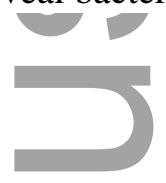

\section{Concluding remarks and perspectives}

Antibiotic resistance in animals is an important and urgent problem posing direct risks to animal and human health, owing to the diversity and abundance of ARGs detected and the potential exchange of antibiotic resistance genes among animals, the environment, and humans. Culture-based, culture-independent, and single-cell genomic approaches can be employed to measure and monitor antibiotic resistance in animals; each has its advantages and disadvantages, and should be selected depending on scientific hypotheses and the objectives of a given study. The goal of investigating antibiotic resistance in animals is to delineate the origin, evolution, development, dissemination, and risk of antibiotic resistance within animal-farming environments, and further within the general environment and humans. The integration of cultivation and molecular technologies provides a more comprehensive understanding of the ecology of antibiotic resistance (Fig. 1). Genome-based studies will also facilitate the identification of new drug targets that could be used for the development of novel antimicrobial agents and therapies.

Presently, most diagnostic tests for antibiotic resistance are based on the phenotypic characterization of isolated bacteria and thus require extended time from specimen collection to results; as a result, patients may be initially treated with broad-spectrum antibiotics. Molecular-based methods may provide a promising means for point-to-need diagnostics of antibiotic resistance and facilitate treatment decisions. Several PCR-based tests have been approved by the U.S. Food and Drug Administration for the detection of antibiotic resistance. ${ }^{200}$ Given that the numerous identified 
resistance mechanisms, high-throughput PCR is a possible solution for comprehensive detection of antibiotic-resistance profiles. Genomic analysis would provide information not only about antibiotic resistance determinants, but also their associated expression-regulatory mechanisms. Standard protocols for molecular diagnosis tests for measuring and monitoring antibiotic resistance, other than the culture-based approach, should be developed for the establishment of a global surveillance system and large-scale comparisons, which would also provide basic information for human health risk assessment of antibiotic resistance.

\section{Acknowledgments}

This project was supported by the National Key Research and Development Plan (2016YFD0800205), the Natural Science Foundation of China (21210008), the Knowledge Innovation Program of the Chinese Academy of Sciences (IUEQN201504), and the Youth Innovation Promotion Association, CAS.

\section{Conflicts of interest}

The authors declare no conflicts of interest.

\section{References}

1. Davies, J.; Davies, D., Origins and evolution of antibiotic resistance. Microbiol Mol Biol Rev 2010, 74, (3), 417-33.

2. Nesme, J.; Simonet, P., The soil resistome: a critical review on antibiotic resistance origins, ecology and dissemination potential in telluric bacteria. Environ Microbiol 2015, 17, (4), 913-930.

3. CDC Achievements in Public Health, 1900-1999: Control of Infectious Diseases; MMWR Weekly 48(29);621-629. July 30.: July 30, 1999. 
4. WHO, Antimicrobial resistance: global report on surveillance. 2014, Available: http://www.who.int/drugresistance/documents/surveillancereport/en/.

5. WHO, Global Antimicrobial Resistance Surveillance System. 2015, Available: http://apps.who.int/iris/bitstream/10665/188783/1/9789241549400_eng.pdf.

6. Allen, H. K., Antibiotic resistance gene discovery in food-producing animals. Curr Opin Microbiol 2014, 19, 25-9.

7. Cabello, F. C.; Godfrey, H. P.; Tomova, A.; Ivanova, L.; Dölz, H.; Millanao, A.; Buschmann, A. $\mathrm{H}$., Antimicrobial use in aquaculture re-examined: its relevance to antimicrobial resistance and to animal and human health. Environ Microbiol 2013, 15, (7), 1917-1942.

8. Perry, J. A.; Westman, E. L.; Wright, G. D., The antibiotic resistome: what's new? Curr Opin Microbiol 2014, 21C, 45-50.

9. Cytryn, E., The soil resistome: The anthropogenic, the native, and the unknown. Soil Biol Biochem 2013, 63, (0), 18-23.

10. Wright, G. D., The antibiotic resistome: the nexus of chemical and genetic diversity. Nat Rev Microbiol 2007, 5, (3), 175-186.

11. D'Costa, V. M.; McGrann, K. M.; Hughes, D. W.; Wright, G. D., Sampling the Antibiotic Resistome. Science 2006, 311, (5759), 374-377.

12. Hu, Y.; Yang, X.; Qin, J.; Lu, N.; Cheng, G.; Wu, N.; Pan, Y.; Li, J.; Zhu, L.; Wang, X.; Meng, Z.; Zhao, F.; Liu, D.; Ma, J.; Qin, N.; Xiang, C.; Xiao, Y.; Li, L.; Yang, H.; Wang, J.; Yang, R.; Gao, G. F.; Wang, J.; Zhu, B., Metagenome-wide analysis of antibiotic resistance genes in a large cohort of human gut microbiota. Nat Commun 2013, 4.

13. Wichmann, F.; Udikovic-Kolic, N.; Andrew, S.; Handelsman, J., Diverse Antibiotic Resistance Genes in Dairy Cow Manure. mBio 2014, 5, (2).

14. Czekalski, N.; Sigdel, R.; Birtel, J.; Matthews, B.; Burgmann, H., Does human activity impact the natural antibiotic resistance background? Abundance of antibiotic resistance genes in 21 Swiss lakes. Environ Int 2015, 81, 45-55.

15. Forsberg, K. J.; Patel, S.; Gibson, M. K.; Lauber, C. L.; Knight, R.; Fierer, N.; Dantas, G., Bacterial phylogeny structures soil resistomes across habitats. Nature 2014, 509, (7502), 612-6.

16. McEachran, A. D.; Blackwell, B. R.; Hanson, J. D.; Wooten, K. J.; Mayer, G. D.; Cox, S. B.; Smith, P. N., Antibiotics, bacteria, and antibiotic resistance genes: aerial transport from cattle feed yards via particulate matter. Environ Health Perspect 2015, 123, (4), 337-43. 
17. Segawa, T.; Takeuchi, N.; Rivera, A.; Yamada, A.; Yoshimura, Y.; Barcaza, G.; Shinbori, K.; Motoyama, H.; Kohshima, S.; Ushida, K., Distribution of antibiotic resistance genes in glacier environments. Environmental Microbiology Reports 2013, 5, (1), 127-134.

18. D'Costa, V. M.; King, C. E.; Kalan, L.; Morar, M.; Sung, W. W. L.; Schwarz, C.; Froese, D.; Zazula, G.; Calmels, F.; Debruyne, R.; Golding, G. B.; Poinar, H. N.; Wright, G. D., Antibiotic resistance is ancient. Nature 2011, 477, (7365), 457-461.

19. Chen, B.; Yang, Y.; Liang, X.; Yu, K.; Zhang, T.; Li, X., Metagenomic profiles of antibiotic resistance genes (ARGs) between human impacted estuary and deep ocean sediments. Environ Sci Technol 2013, 47, (22), 12753-60.

20. Levy, S. B.; Marshall, B., Antibacterial resistance worldwide: causes, challenges and responses. Nat Med 2004, 10, (12 Suppl), S122-9.

21. Zhang, Q.-Q.; Ying, G.-G.; Pan, C.-G.; Liu, Y.-S.; Zhao, J.-L., Comprehensive Evaluation of Antibiotics Emission and Fate in the River Basins of China: Source Analysis, Multimedia Modeling, and Linkage to Bacterial Resistance. Environ Sci Technol 2015, 49, (11), 6772-6782.

22. Meyer, E.; Gastmeier, P.; Deja, M.; Schwab, F., Antibiotic consumption and resistance: Data from Europe and Germany. Int J Med Microbiol 2013, 303, (6-7), 388-395.

23. Looft, T;; Johnson, T. A.; Allen, H. K.; Bayles, D. O.; Alt, D. P.; Stedtfeld, R. D.; Sul, W. J.; Stedtfeld, T. M.; Chai, B.; Cole, J. R.; Hashsham, S. A.; Tiedje, J. M.; Stanton, T. B., In-feed antibiotic effects on the swine intestinal microbiome. Proc Natl Acad Sci U S A 2012, 109, (5), $1691-6$.

24. Zhu, Y. G.; Johnson, T. A.; Su, J. Q.; Qiao, M.; Guo, G. X.; Stedtfeld, R. D.; Hashsham, S. A.; Tiedje, J. M., Diverse and abundant antibiotic resistance genes in Chinese swine farms. Proc Natl Acad Sci US A 2013, 110, (9), 3435-40.

25. Li, J.; Wang, T.; Shao, B.; Shen, J.; Wang, S.; Wu, Y., Plasmid-mediated quinolone resistance genes and antibiotic residues in wastewater and soil adjacent to swine feedlots: potential transfer to agricultural lands. Environ Health Perspect 2012, 120, (8), 1144-9.

26. Zwonitzer, M. R.; Soupir, M. L.; Jarboe, L. R.; Smith, D. R., Quantifying Attachment and Antibiotic Resistance of from Conventional and Organic Swine Manure. Journal of Environment Quality 2016, 45, (2), 609.

27. He, L.-Y.; Ying, G.-G.; Liu, Y.-S.; Su, H.-C.; Chen, J.; Liu, S.-S.; Zhao, J.-L., Discharge of swine wastes risks water quality and food safety: Antibiotics and antibiotic resistance genes from swine sources to the receiving environments. Environ Int 2016, 92-93, 210-219. 
28. Li, B.; Yang, Y.; Ma, L.; Ju, F.; Guo, F.; Tiedje, J. M.; Zhang, T., Metagenomic and network analysis reveal wide distribution and co-occurrence of environmental antibiotic resistance genes. ISME J 2015, 9, (11), 2490-502.

29. Durso, L. M.; Harhay, G. P.; Bono, J. L.; Smith, T. P., Virulence-associated and antibiotic resistance genes of microbial populations in cattle feces analyzed using a metagenomic approach. $J$ Microbiol Methods 2011, 84, (2), 278-82.

30. Thanner, S.; Drissner, D.; Walsh, F., Antimicrobial Resistance in Agriculture. mBio 2016, 7, (2).

31. Heuer, H.; Schmitt, H.; Smalla, K., Antibiotic resistance gene spread due to manure application on agricultural fields. Curr Opin Microbiol 2011, 14, (3), 236-243.

32. Marshall, B. M.; Levy, S. B., Food animals and antimicrobials: impacts on human health. Clinical microbiology reviews 2011, 24, (4), 718-33.

33. Bonomo, R. A.; Szabo, D., Mechanisms of multidrug resistance in Acinetobacter species and Pseudomonas aeruginosa. Clin Infect Dis 2006, 43 Suppl 2, S49-56.

34. Livermore, D. M.; Canton, R.; Gniadkowski, M.; Nordmann, P.; Rossolini, G. M.; Arlet, G.; Ayala, J.; Coque, T. M.; Kern-Zdanowicz, I.; Luzzaro, F.; Poirel, L.; Woodford, N., CTX-M: changing the face of ESBLs in Europe. J Antimicrob Chemother 2007, 59, (2), 165-74.

35. Wang, C.; Sui, Z.; Leclercq, S. O.; Zhang, G.; Zhao, M.; Chen, W.; Feng, J., Functional characterization and phylogenetic analysis of acquired and intrinsic macrolide phosphotransferases in the Bacillus cereus group. Environ Microbiol 2015, 17, (5), 1560-73.

36. Stokes, H. W.; Gillings, M. R., Gene flow, mobile genetic elements and the recruitment of antibiotic resistance genes into Gram-negative pathogens. FEMS Microbiol Rev 2011, 35, (5), 790-819.

37. Poirel, L.; Cattoir, V.; Nordmann, P., Plasmid-Mediated Quinolone Resistance; Interactions between Human, Animal, and Environmental Ecologies. Front Microbiol 2012, 3, 24.

38. Forsberg, K. J.; Reyes, A.; Wang, B.; Selleck, E. M.; Sommer, M. O. A.; Dantas, G., The Shared Antibiotic Resistome of Soil Bacteria and Human Pathogens. Science 2012, 337, (6098), 1107-1111.

39. FAO-OIE-WHO, The FAO-OIE-WHO Collaboration. A Tripartite Concept Note. http://web.oie.int/downld/FINAL_CONCEPT_NOTE_Hanoi.pdf. 2010.

40. Martinez, J. L.; Coque, T. M.; Baquero, F., What is a resistance gene? Ranking risk in resistomes. Nat Rev Micro 2015, 13, (2), 116-123. 
41. Brandt, K. K.; Amézquita, A.; Backhaus, T.; Boxall, A.; Coors, A.; Heberer, T.; Lawrence, J. R.; Lazorchak, J.; Schönfeld, J.; Snape, J. R.; Zhu, Y.-G.; Topp, E., Ecotoxicological assessment of antibiotics: A call for improved consideration of microorganisms. Environ Int 2015, 85, 189-205.

42. Monier, J.-M.; Demanèche, S.; Delmont, T. O.; Mathieu, A.; Vogel, T. M.; Simonet, P., Metagenomic exploration of antibiotic resistance in soil. Curr Opin Microbiol 2011, 14, (3), 229-235.

43. Luby, E.; Ibekwe, A. M.; Zilles, J.; Pruden, A., Molecular Methods for Assessment of Antibiotic Resistance in Agricultural Ecosystems: Prospects and Challenges. Journal of Environment Quality 2016, $45,(2), 441$.

44. McLain, J. E; Cytryn, E.; Durso, L. M.; Young, S., Culture-based Methods for Detection of Antibiotic Resistance in Agroecosystems: Advantages, Challenges, and Gaps in Knowledge. Journal of Environment Quality 2016, 45, (2), 432.

45. Bondarczuk, K.; Markowicz, A.; Piotrowska-Seget, Z., The urgent need for risk assessment on the antibiotic resistance spread via sewage sludge land application. Environ Int 2016, 87, 49-55.

46. Schmieder, R.; Edwards, R., Insights into antibiotic resistance through metagenomic approaches. Future microbiology 2012, 7, (1), 73-89.

47. Forslund, K.; Sunagawa, S.; Coelho, L. P.; Bork, P., Metagenomic insights into the human gut resistome and the forces that shape it. BioEssays 2014, 36, (3), 316-329.

48. de Castro, A. P.; Fernandes Gda, R.; Franco, O. L., Insights into novel antimicrobial compounds and antibiotic resistance genes from soil metagenomes. Front Microbiol 2014, 5, 489.

49. McArthur, A. G.; Wright, G. D., Bioinformatics of antimicrobial resistance in the age of molecular epidemiology. Curr Opin Microbiol 2015, 27, 45-50.

50. Fitzpatrick, D.; Walsh, F., Antibiotic resistance genes across a wide variety of metagenomes. FEMS Microbiol Ecol 2016, 92, (2), fiv168.

51. Czekalski, N.; Berthold, T.; Caucci, S.; Egli, A.; Burgmann, H., Increased levels of multiresistant bacteria and resistance genes after wastewater treatment and their dissemination into lake geneva, Switzerland. Front Microbiol 2012, 3, 106.

52. Duarte, A.; Santos, A.; Manageiro, V.; Martins, A.; Fraqueza, M. J.; Canica, M.; Domingues, F. C.; Oleastro, M., Human, food and animal Campylobacter spp. isolated in Portugal: high genetic diversity and antibiotic resistance rates. Int J Antimicrob Agents 2014, 44, (4), 306-13.

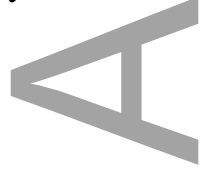

This article is protected by copyright. All rights reserved. 
53. Rothrock, M. J.; Hiett, K. L.; Guard, J. Y.; Jackson, C. R., Antibiotic Resistance Patterns of Major Zoonotic Pathogens from All-Natural, Antibiotic-Free, Pasture-Raised Broiler Flocks in the Southeastern United States. Journal of Environment Quality 2016, 45, (2), 593.

54. Woodford, N.; Turton, J. F.; Livermore, D. M., Multiresistant Gram-negative bacteria: the role of high-risk clones in the dissemination of antibiotic resistance. FEMS Microbiol Rev 2011, 35, (5), 736-755.

55. Willems, R. J. L.; Hanage, W. P.; Bessen, D. E.; Feil, E. J., Population biology of Gram-positive pathogens: high-risk clones for dissemination of antibiotic resistance. FEMS Microbiol Rev 2011, 35, (5), 872-900.

56. Rogers, B. A.; Sidjabat, H. E.; Paterson, D. L., Escherichia coli O25b-ST131: a pandemic, multiresistant, community-associated strain. J Antimicrob Chemother 2011, 66, (1), 1-14.

57. Schoen, M. E; ; Ashbolt, N. J., An in-premise model for Legionella exposure during showering events. Water Res 2011, 45, (18), 5826-36.

58. McEwen, S. A., Quantitative human health risk assessments of antimicrobial use in animals and selection of resistance: a review of publicly available reports. Rev Sci Tech 2012, 31, (1), 261-76.

59. Wang, Y.; Dong, Y.; Deng, F.; Liu, D.; Yao, H.; Zhang, Q.; Shen, J.; Liu, Z.; Gao, Y.; Wu, C.; Shen, Z., Species shift and multidrug resistance of Campylobacter from chicken and swine, China, 2008-14. J Antimicrob Chemother 2015.

60. Wendlandt, S.; Kadlec, K.; Fessler, A. T.; Monecke, S.; Ehricht, R.; van de Giessen, A. W.; Hengeveld, P. D.; Huijsdens, X.; Schwarz, S.; van Duijkeren, E., Resistance phenotypes and genotypes of methicillin-resistant Staphylococcus aureus isolates from broiler chickens at slaughter and abattoir workers. J Antimicrob Chemother 2013, 68, (11), 2458-2463.

61. Smith, M.; Do, T. N.; Gibson, J. S.; Jordan, D.; Cobbold, R. N.; Trott, D. J., Comparison of antimicrobial resistance phenotypes and genotypes in enterotoxigenic Escherichia coli isolated from Australian and Vietnamese pigs. J Glob Antimicrob Re 2014, 2, (3), 162-167.

62. Matayoshi, M.; Kitano, T.; Sasaki, T.; Nakamura, M., Resistance phenotypes and genotypes among multiple-antimicrobial-resistant Salmonella enterica subspecies enterica serovar Choleraesuis strains isolated between 2008 and 2012 from slaughter pigs in Okinawa Prefecture, Japan. J Vet Med Sci 2015, 77, (6), 705-710.

63. Li, L. P.; Feng, W. W.; Zhang, Z. P.; Xue, H. P.; Zhao, X., Macrolide-lincosamide-streptogramin resistance phenotypes and genotypes of coagulase-positive Staphylococcus aureus and coagulase-negative staphylococcal isolates from bovine mastitis. Bmc Vet Res 2015, 11. 
64. Zhao, S.; Tyson, G. H.; Chen, Y.; Li, C.; Mukherjee, S.; Young, S.; Lam, C.; Folster, J. P.; Whichard, J. M.; McDermott, P. F., Whole-Genome Sequencing Analysis Accurately Predicts Antimicrobial Resistance Phenotypes in Campylobacter spp. Appl Environ Microbiol 2016, 82, (2), 459-466.

65. Kim, S.; Lieberman, T. D.; Kishony, R., Alternating antibiotic treatments constrain evolutionary paths to multidrug resistance. Proc Natl Acad Sci U S A 2014, 111, (40), 14494-9.

66. Fernandez-Alarcon, C.; Singer, R. S.; Johnson, T. J., Comparative genomics of multidrug resistance-encoding IncA/C plasmids from commensal and pathogenic Escherichia coli from multiple animal sources. PLoS One 2011, 6, (8), e23415.

67. Leclereq, S. O.; Wang, C.; Sui, Z.; Wu, H.; Zhu, B.; Deng, Y.; Feng, J., A multi-player game: Species of Clostridium, Acinetobacter, and Pseudomonas are responsible for the persistence of antibiotic resistance genes in manure-treated soils. Environmental microbiology 2016.

68. Lester, C. H.; Frimodt-Moller, N.; Sorensen, T. L.; Monnet, D. L.; Hammerum, A. M., In vivo transfer of the vanA resistance gene from an Enterococcus faecium isolate of animal origin to an $\mathrm{E}$. faecium isolate of human origin in the intestines of human volunteers. Antimicrob Agents Chemother 2006, 50, (2), 596-9.

69. Wang, Y.; Lv, Y.; Cai, J.; Schwarz, S.; Cui, L.; Hu, Z.; Zhang, R.; Li, J.; Zhao, Q.; He, T.; Wang, D.; Wang, Z.; Shen, Y.; Li, Y.; Fessler, A. T.; Wu, C.; Yu, H.; Deng, X.; Xia, X.; Shen, J., A novel gene, optrA, that confers transferable resistance to oxazolidinones and phenicols and its presence in Enterococcus faecalis and Enterococcus faecium of human and animal origin. J Antimicrob Chemother 2015, 70, (8), 2182-90.

70. Ma, L.; Xia, Y.; Li, B.; Yang, Y.; Li, L. G.; Tiedje, J. M.; Zhang, T., Metagenomic Assembly Reveals Hosts of Antibiotic Resistance Genes and the Shared Resistome in Pig, Chicken, and Human Feces. Environ Sci Technol 2016, 50, (1), 420-7.

71. Soucy, S. M.; Huang, J.; Gogarten, J. P., Horizontal gene transfer: building the web of life. Nat Rev Genet 2015, 16, (8), 472-82.

72. Metcalf, J. A.; Funkhouser-Jones, L. J.; Brileya, K.; Reysenbach, A. L.; Bordenstein, S. R., Antibacterial gene transfer across the tree of life. Elife 2014, 3.

73. Andam, C. P.; Fournier, G. P.; Gogarten, J. P., Multilevel populations and the evolution of antibiotic resistance through horizontal gene transfer. FEMS Microbiol Rev 2011, 35, (5), 756-767.

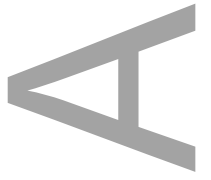

This article is protected by copyright. All rights reserved. 
74. Fricke, W. F.; Welch, T. J.; McDermott, P. F.; Mammel, M. K.; LeClerc, J. E.; White, D. G.; Cebula, T. A.; Ravel, J., Comparative genomics of the IncA/C multidrug resistance plasmid family. $J$ Bacteriol 2009, 191, (15), 4750-7.

75. Fournier, P. E.; Vallenet, D.; Barbe, V.; Audic, S.; Ogata, H.; Poirel, L.; Richet, H.; Robert, C.; Mangenot, S.; Abergel, C.; Nordmann, P.; Weissenbach, J.; Raoult, D.; Claverie, J. M., Comparative genomics of multidrug resistance in Acinetobacter baumannii. Plos Genet 2006, 2, (1), e7.

76. Bradley, P.; Gordon, N. C.; Walker, T. M.; Dunn, L.; Heys, S.; Huang, B.; Earle, S.; Pankhurst, L. J.; Anson, L.; de Cesare, M.; Piazza, P.; Votintseva, A. A.; Golubchik, T.; Wilson, D. J.; Wyllie, D. H.; Diel, R.; Niemann, S.; Feuerriegel, S.; Kohl, T. A.; Ismail, N.; Omar, S. V.; Smith, E. G.; Buck, D.; McVean, G.; Walker, A. S.; Peto, T. E.; Crook, D. W.; Iqbal, Z., Rapid antibiotic-resistance predictions from genome sequence data for Staphylococcus aureus and Mycobacterium tuberculosis. Nat Commun 2015, 6, 10063.

77. Mather, A. E.; Reid, S. W. J.; Maskell, D. J.; Parkhill, J.; Fookes, M. C.; Harris, S. R.; Brown, D. J.; Coia, J. E.; Mulvey, M. R.; Gilmour, M. W.; Petrovska, L.; de Pinna, E.; Kuroda, M.; Akiba, M.; Izumiya, H.; Connor, T. R.; Suchard, M. A.; Lemey, P.; Mellor, D. J.; Haydon, D. T.; Thomson, N. R., Distinguishable Epidemics of Multidrug-Resistant Salmonella Typhimurium DT104 in Different Hosts. Science 2013, 341, (6153), 1514-1517.

78. Mather, A. E.; Matthews, L.; Mellor, D. J.; Reeve, R.; Denwood, M. J.; Boerlin, P.; Reid-Smith, R. J.; Brown, D. J.; Coia, J. E.; Browning, L. M.; Haydon, D. T.; Reid, S. W., An ecological approach to assessing the epidemiology of antimicrobial resistance in animal and human populations. Proc.

\section{Biol. Sci. 2011.}

79. Woolhouse, M. E. J.; Ward, M. J., Sources of Antimicrobial Resistance. Science 2013, 341, (6153), 1460-1461.

80. Ashbolt, N. J.; Amezquita, A.; Backhaus, T.; Borriello, P.; Brandt, K. K.; Collignon, P.; Coors, A.; Finley, R.; Gaze, W. H.; Heberer, T.; Lawrence, J. R.; Larsson, D. G.; McEwen, S. A.; Ryan, J. J.; Schonfeld, J.; Silley, P.; Snape, J. R.; Van den Eede, C.; Topp, E., Human Health Risk Assessment (HHRA) for environmental development and transfer of antibiotic resistance. Environ Health Perspect 2013, 121, (9), 993-1001.

81. Zhang, S.; Ye, C.; Lin, W.; Yu, X., Response to Comment on "UV Disinfection Induces a VBNC State in Escherichia coli and Pseudomonas aeruginosa". Environ Sci Technol 2015, 49, (17), 10752-3.

82. Tringe, S. G.; Rubin, E. M., Metagenomics: DNA sequencing of environmental samples. Nat Rev Genet 2005, 6, (11), 805-814.

83. Hugenholtz, P.; Tyson, G. W., Microbiology: metagenomics. Nature 2008, 455, (7212), 481-483. 
84. Looft, T.; Allen, H. K.; Cantarel, B. L.; Levine, U. Y.; Bayles, D. O.; Alt, D. P.; Henrissat, B.; Stanton, T. B., Bacteria, phages and pigs: the effects of in-feed antibiotics on the microbiome at different gut locations. The ISME journal 2014, 8, (8), 1566-76.

85. Qu, A.; Brulc, J. M.; Wilson, M. K.; Law, B. F.; Theoret, J. R.; Joens, L. A.; Konkel, M. E.; Angly, F.; Dinsdale, E. A.; Edwards, R. A.; Nelson, K. E.; White, B. A., Comparative metagenomics reveals host specific metavirulomes and horizontal gene transfer elements in the chicken cecum microbiome. PLoS One 2008, 3, (8), e2945.

86. Tun, H. M.; Brar, M. S.; Khin, N.; Jun, L.; Hui, R. K.; Dowd, S. E.; Leung, F. C., Gene-centric metagenomics analysis of feline intestinal microbiome using 454 junior pyrosequencing. J Microbiol Methods 2012, 88, (3), 369-76.

87. Guo, X.; Liu, S.; Wang, Z.; Zhang, X. X.; Li, M.; Wu, B., Metagenomic profiles and antibiotic resistance genes in gut microbiota of mice exposed to arsenic and iron. Chemosphere 2014, 112, 1-8.

88. Yin, J,; Zhang, X. X.; Wu, B.; Xian, Q., Metagenomic insights into tetracycline effects on microbial community and antibiotic resistance of mouse gut. Ecotoxicology 2015, 24, (10), 2125-32.

89. Field, W.; Hershberg, R., Alarmingly High Segregation Frequencies of Quinolone Resistance Alleles within Human and Animal Microbiomes Are Not Explained by Direct Clinical Antibiotic Exposure. Genome Biol Evol 2015, 7, (6), 1743-57.

90. Baker-Austin, C.; Wright, M. S.; Stepanauskas, R.; McArthur, J. V., Co-selection of antibiotic and metal resistance. Trends Microbiol 2006, 14, (4), 176-82.

91. Hu, H. W.; Wang, J. T.; Li, J.; Li, J. J.; Ma, Y. B.; Chen, D.; He, J. Z., Field-based evidence for copper contamination induced changes of antibiotic resistance in agricultural soils. Environ Microbiol 2016, n/a-n/a.

92. Liu, B., Pop, M., ARDB - antibiotic resistance genes database. Nucleic Acids Res 2009, 37, (suppl 1), D443-D447.

93. McArthur, A. G.; Waglechner, N.; Nizam, F.; Yan, A.; Azad, M. A.; Baylay, A. J.; Bhullar, K.; Canova, M. J.; De Pascale, G.; Ejim, L., The comprehensive antibiotic resistance database. Antimicrobial agents and chemotherapy 2013, 57, (7), 3348-3357.

94. Yang, Y.; Li, B.; Ju, F.; Zhang, T., Exploring variation of antibiotic resistance genes in activated sludge over a four-year period through a metagenomic approach. Environ Sci Technol 2013, 47, (18), 10197-205. 
95. Yang, Y.; Jiang, X.; Chai, B.; Ma, L.; Li, B.; Zhang, A.; Cole, J. R.; Tiedje, J. M.; Zhang, T., ARGs-OAP: online analysis pipeline for antibiotic resistance genes detection from metagenomic data using an integrated structured ARG-database. Bioinformatics 2016, btw136.

96. Riesenfeld, C. S.; Goodman, R. M.; Handelsman, J., Uncultured soil bacteria are a reservoir of new antibiotic resistance genes. Environ Microbiol 2004, 6, (9), 981-989.

97. Sommer, M. O. A.; Dantas, G.; Church, G. M., Functional Characterization of the Antibiotic Resistance Reservoir in the Human Microflora. Science 2009, 325, (5944), 1128-1131.

98. Donato, J. J.; Moe, L. A.; Converse, B. J.; Smart, K. D.; Berklein, F. C.; McManus, P. S.; Handelsman, J., Metagenomic analysis of apple orchard soil reveals antibiotic resistance genes encoding predicted bifunctional proteins. Appl Environ Microbiol 2010, 76, (13), 4396-401.

99. Torres-Cortes, G.; Millan, V.; Ramirez-Saad, H. C.; Nisa-Martinez, R.; Toro, N.;

Martinez-Abarca, F., Characterization of novel antibiotic resistance genes identified by functional metagenomics on soil samples. Environ Microbiol 2011, 13, (4), 1101-14.

100. Su, J. Q.; Wei, B.; Xu, C. Y.; Qiao, M.; Zhu, Y. G., Functional metagenomic characterization of antibiotic resistance genes in agricultural soils from China. Environ Int 2014, 65, 9-15.

101. Kazimierczak, K. A.; Scott, K. P.; Kelly, D.; Aminov, R. I., Tetracycline Resistome of the Organic Pig Gut. Appl Environ Microbiol 2009, 75, (6), 1717-1722.

102. Nalbantoglu, O.; Way, S.; Hinrichs, S.; Sayood, K., RAIphy: Phylogenetic classification of metagenomies samples using iterative refinement of relative abundance index profiles. Bmc

Bioinformatics 2011, 12, (1), 41.

103. Warnes, S. L.; Highmore, C. J.; Keevil, C. W., Horizontal transfer of antibiotic resistance genes on abiotic touch surfaces: implications for public health. mBio 2012, 3, (6).

104. Zhang, T.; Zhang, X.-X.; Ye, L., Plasmid Metagenome Reveals High Levels of Antibiotic Resistance Genes and Mobile Genetic Elements in Activated Sludge. PLoS One 2011, 6, (10), e26041.

105. Gillings, M. R.; Gaze, W. H.; Pruden, A.; Smalla, K.; Tiedje, J. M.; Zhu, Y. G., Using the class 1 integron-integrase gene as a proxy for anthropogenic pollution. ISME J 2015, 9, (6), 1269-79.

106. Stalder, T.; Barraud, O.; Jove, T.; Casellas, M.; Gaschet, M.; Dagot, C.; Ploy, M.-C., Quantitative and qualitative impact of hospital effluent on dissemination of the integron pool. ISME J 2014, 8, (4), 768-777.

This article is protected by copyright. All rights reserved. 
107. Modi, S. R.; Lee, H. H.; Spina, C. S.; Collins, J. J., Antibiotic treatment expands the resistance reservoir and ecological network of the phage metagenome. Nature 2013, 499, (7457), 219-22.

108. Zhou, J.; He, Z.; Yang, Y.; Deng, Y.; Tringe, S. G.; Alvarez-Cohen, L., High-throughput metagenomic technologies for complex microbial community analysis: open and closed formats. mBio 2015, 6, (1), e02288-14.

109. DeSantis, T. Z.; Brodie, E. L.; Moberg, J. P.; Zubieta, I. X.; Piceno, Y. M.; Andersen, G. L., High-density universal $16 \mathrm{~S}$ rRNA microarray analysis reveals broader diversity than typical clone library when sampling the environment. Microb Ecol 2007, 53, (3), 371-383.

110. Zhou, G. P.; Wen, S. P.; Liu, Y. W.; Li, R. R.; Zhong, X. Y.; Feng, L.; Wang, L.; Cao, B. Y., Development of a DNA microarray for detection and identification of Legionella pneumophila and ten other pathogens in drinking water. Int J Food Microbiol 2011, 145, (1), 293-300.

111. Hazen, T. C.; Dubinsky, E. A.; DeSantis, T. Z.; Andersen, G. L.; Piceno, Y. M.; Singh, N.; Jansson, J. K.; Probst, A.; Borglin, S. E.; Fortney, J. L.; Stringfellow, W. T.; Bill, M.; Conrad, M. E.; Tom, L. M.; Chavarria, K. L.; Alusi, T. R.; Lamendella, R.; Joyner, D. C.; Spier, C.; Baelum, J.; Auer, M.; Zemla, M. L.; Chakraborty, R.; Sonnenthal, E. L.; D'haeseleer, P.; Holman, H. Y. N.; Osman, S.; Lu, Z. M.; Van Nostrand, J. D.; Deng, Y.; Zhou, J. Z.; Mason, O. U., Deep-Sea Oil Plume Enriches Indigenous Oil-Degrading Bacteria. Science 2010, 330, (6001), 204-208.

112. DeAngelis, K. M.; Wu, C. H.; Beller, H. R.; Brodie, E. L.; Chakraborty, R.; DeSantis, T. Z.; Fortney, J. L.; Hazen, T. C.; Osman, S. R.; Singer, M. E.; Tom, L. M.; Andersen, G. L., PCR Amplification-Independent Methods for Detection of Microbial Communities by the High-Density Microarray PhyloChip. Appl Environ Microbiol 2011, 77, (18), 6313-6322.

113. Franke-Whittle, I. H.; Knapp, B. A.; Fuchs, J.; Kaufmann, R.; Insam, H., Application of COMPOCHIP Microarray to Investigate the Bacterial Communities of Different Composts. Microb Ecol 2009, 57, (3), 510-521.

114. Paliy, O.; Kenche, H.; Abernathy, F.; Michail, S., High-Throughput Quantitative Analysis of the Human Intestinal Microbiota with a Phylogenetic Microarray. Appl Environ Microbiol 2009, 75, (11), 3572-3579.

115. Zimenkov, D. V.; Kulagina, E. V.; Antonova, O. V.; Krasnova, M. A.; Chernyaeva, E. N.; Zhuravlev, V. Y.; Kuz'min, A. V.; Popov, S. A.; Zasedatelev, A. S.; Gryadunov, D. A., Evaluation of a Low-Density Hydrogel Microarray Technique for Mycobacterial Species Identification. J Clin Microbiol 2015, 53, (4), 1103-1114.

116. Kostic, T.; Stessl, B.; Wagner, M.; Sessitsch, A.; Bodrossy, L., Microbial diagnostic microarray for food- and water-borne pathogens. Microbial Biotechnology 2010, 3, (4), 444-454. 
117. Shi, Y.-H.; Chen, J.; Li, C.-H.; Lu, X.-J.; Zhang, D.-M.; Li, H.-Y.; Zhao, Z.-X.; Li, M.-Y., Detection of bacterial pathogens in aquaculture samples by DNA microarray analysis. Aquaculture 2012, 338-341, 29-35.

118. Kakinuma, K.; Fukushima, M.; Kawaguchi, R., Detection and identification of Escherichia coli, Shigella, and Salmonella by microarrays using the gyrB gene. Biotechnol Bioeng 2003, 83, (6), 721-728.

119. Lee, P. K. H.; Cheng, D.; Hu, P.; West, K. A.; Dick, G. J.; Brodie, E. L.; Andersen, G. L.; Zinder, S. H.; He, J. Z.; Alvarez-Cohen, L., Comparative genomics of two newly isolated Dehalococcoides strains and an enrichment using a genus microarray. ISME J 2011, 5, (6), 1014-1024.

120. Hug, L. A.; Salehi, M.; Nuin, P.; Tillier, E. R.; Edwards, E. A., Design and Verification of a Pangenome Microarray Oligonucleotide Probe Set for Dehalococcoides spp. Appl Environ Microbiol 2011, 77, (15), 5361-5369.

121. Shilova, I. N.; Robidart, J. C.; Tripp, H. J.; Turk-Kubo, K.; Wawrik, B.; Post, A. F.; Thompson, A. W.; Ward, B.; Hollibaugh, J. T.; Millard, A.; Ostrowski, M.; Scanlan, D. J.; Paerl, R. W.; Stuart, R.; Zehr, J.P., A microarray for assessing transcription from pelagic marine microbial taxa. ISME J 2014, 8, (7), 1476-1491.

122. Tu, Q.; Yu, H.; He, Z.; Deng, Y.; Wu, L.; Van Nostrand, J. D.; Zhou, A.; Voordeckers, J.; Lee, Y. J.; Qin, Y.; Hemme, C. L.; Shi, Z.; Xue, K.; Yuan, T.; Wang, A.; Zhou, J., GeoChip 4: a functional gene-array-based high-throughput environmental technology for microbial community analysis. $\mathrm{Mol}$ Ecol Resour 2014, 14, (5), 914-28.

123. Tu, Q.; He, Z.; Li, Y.; Chen, Y.; Deng, Y.; Lin, L.; Hemme, C. L.; Yuan, T.; Van Nostrand, J. D.; Wu, L.; Zhou, X.; Shi, W.; Li, L.; Xu, J.; Zhou, J., Development of HuMiChip for functional profiling of human microbiomes. PLoS One 2014, 9, (3), e90546.

124. Disney, M. D.; Magnet, S.; Blanchard, J. S.; Seeberger, P. H., Aminoglycoside microarrays to study antibiotic resistance. Angew Chem Int Ed Engl 2004, 43, (12), 1591-4.

125. Volokhov, D.; Chizhikov, V.; Chumakov, K.; Rasooly, A., Microarray analysis of erythromycin resistance determinants. J Appl Microbiol 2003, 95, (4), 787-98.

126. Mendonca, N.; Figueiredo, R.; Mendes, C.; Card, R. M.; Anjum, M. F.; da Silva, G. J., Microarray Evaluation of Antimicrobial Resistance and Virulence of Escherichia coli Isolates from Portuguese Poultry. Antibiotics (Basel) 2016, 5, (1). 
127. Strauss, C.; Endimiani, A.; Perreten, V., A novel universal DNA labeling and amplification system for rapid microarray-based detection of 117 antibiotic resistance genes in Gram-positive bacteria. J Microbiol Methods 2015, 108, 25-30.

128. Perreten, V.; Vorlet-Fawer, L.; Slickers, P.; Ehricht, R.; Kuhnert, P.; Frey, J., Microarray-based detection of 90 antibiotic resistance genes of gram-positive bacteria. J Clin Microbiol 2005, 43, (5), 2291-302.

129. Booth, S. A.; Drebot, M. A.; Martin, I. E.; Ng, L. K., Design of oligonucleotide arrays to detect point mutations: molecular typing of antibiotic resistant strains of Neisseria gonorrhoeae and hantavirus infected deer mice. Molecular and Cellular Probes 2003, 17, (2-3), 77-84.

130. Zhang,Y.; Xie, J.; Liu, M.; Tian, Z.; He, Z.; van Nostrand, J. D.; Ren, L.; Zhou, J.; Yang, M., Microbial community functional structure in response to antibiotics in pharmaceutical wastewater treatment systems. Water Res 2013, 47, (16), 6298-6308.

131. Wedley, A. L.; Dawson, S.; Maddox, T. W.; Coyne, K. P.; Pinchbeck, G. L.; Clegg, P.; Jamrozy, D.; Fielder, M. D.; Donovan, D.; Nuttall, T.; Williams, N. J., Carriage of Staphylococcus species in the veterinary visiting dog population in mainland UK: molecular characterisation of resistance and virulence. Vet Microbiol 2014, 170, (1-2), 81-8.

132. Nemeghaire, S.; Argudin, M. A.; Haesebrouck, F.; Butaye, P., Molecular epidemiology of methicillin-resistant Staphylococcus sciuri in healthy chickens. Vet Microbiol 2014, 171, (3-4), $357-63$.

133. Huber, H.; Giezendanner, N.; Stephan, R.; Zweifel, C., Genotypes, Antibiotic Resistance Profiles and Microarray-Based Characterization of Methicillin-Resistant Staphylococcus aureus Strains Isolated from Livestock and Veterinarians in Switzerland. Zoonoses Public Hlth 2011, 58, (5), 343-349.

134. Garneau, P.; Labrecque, O.; Maynard, C.; Messier, S.; Masson, L.; Archambault, M.; Harel, J., Use of a Bacterial Antimicrobial Resistance Gene Microarray for the Identification of Resistant Staphylococcus aureus. Zoonoses Public Hlth 2010, 57, 94-99.

135.Zou, W.; Frye, J. G.; Chang, C. W.; Liu, J.; Cerniglia, C. E.; Nayak, R., Microarray analysis of antimicrobial resistance genes in Salmonella enterica from preharvest poultry environment. J Appl Microbiol 2009, 107, (3), 906-914.

136. Ma, M. G.; Wang, H. N.; Yu, Y.; Zhang, D.; Liu, S. G., Detection of antimicrobial resistance genes of pathogenie Salmonella from swine with DNA microarray. J Vet Diagn Invest 2007, 19, (2), $161-167$.

This article is protected by copyright. All rights reserved. 
137. Jakobsen, L.; Garneau, P.; Kurbasic, A.; Bruant, G.; Stegger, M.; Harel, J.; Jensen, K. S.; Brousseau, R.; Hammerum, A. M.; Frimodt-Moller, N., Microarray-based detection of extended virulence and antimicrobial resistance gene profiles in phylogroup B2 Escherichia coli of human, meat and animal origin. J Med Microbiol 2011, 60, (Pt 10), 1502-11.

138. Lee, Y.-J.; van Nostrand, J. D.; Tu, Q.; Lu, Z.; Cheng, L.; Yuan, T.; Deng, Y.; Carter, M. Q.; He, Z.; Wu, L.; Yang, F.; Xu, J.; Zhou, J., The PathoChip, a functional gene array for assessing pathogenic properties of diverse microbial communities. ISME J 2013, 7, (10), 1974-1984.

139. Li, X.; Harwood, V. J.; Nayak, B.; Staley, C.; Sadowsky, M. J.; Weidhaas, J., A Novel Microbial Source Tracking Microarray for Pathogen Detection and Fecal Source Identification in Environmental Systems. Environ Sci Technol 2015.

140. Wang, X.; Xia, Y.; Wen, X.; Yang, Y.; Zhou, J., Microbial community functional structures in wastewater treatment plants as characterized by GeoChip. PLoS One 2014, 9, (3), e93422.

141. Gaze, W. H.; Zhang, L.; Abdouslam, N. A.; Hawkey, P. M.; Calvo-Bado, L.; Royle, J.; Brown, H.; Davis, S.; Kay, P.; Boxall, A. B.; Wellington, E. M., Impacts of anthropogenic activity on the ecology of class 1 integrons and integron-associated genes in the environment. ISME J 2011, 5, (8), 1253-61.

142. Luo, Y.; Mao, D.; Rysz, M.; Zhou, Q.; Zhang, H.; Xu, L.; P, J. J. A., Trends in antibiotic resistance genes occurrence in the Haihe River, China. Environmental science \& technology 2010, 44, (19), 7220-5.

143. Zhang, X. X.; Zhang, T., Occurrence, abundance, and diversity of tetracycline resistance genes in 15 sewage treatment plants across China and other global locations. Environmental science \& technology 2011, 45, (7), 2598-604.

144. Joy, S. R.; Bartelt-Hunt, S. L.; Snow, D. D.; Gilley, J. E.; Woodbury, B. L.; Parker, D. B.; Marx, D. B.; Li, X., Fate and transport of antimicrobials and antimicrobial resistance genes in soil and runoff following land application of swine manure slurry. Environ Sci Technol 2013, 47, (21), 12081-8.

145. Heuer, H.; Smalla, K., Manure and sulfadiazine synergistically increased bacterial antibiotic resistance in soil over at least two months. Environ Microbiol 2007, 9, (3), 657-66.

146. Marti, R.; Tien, Y. C.; Murray, R.; Scott, A.; Sabourin, L.; Topp, E., Safely coupling livestock and crop production systems: how rapidly do antibiotic resistance genes dissipate in soil following a commercial application of swine or dairy manure? Appl Environ Microbiol 2014, 80, (10), 3258-65.

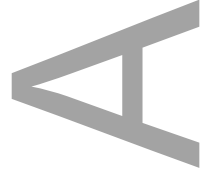

This article is protected by copyright. All rights reserved. 
147. Ryu, H.; Elk, M.; Khan, I. U.; Harwood, V. J.; Molina, M.; Edge, T. A.; Domingo, J. S., Comparison of two poultry litter qPCR assays targeting the 16S rRNA gene of Brevibacterium sp. Water Res 2014, 48, 613-21.

148. Chen, J.; Yu, Z.; Michel, F. C.; Wittum, T.; Morrison, M., Development and Application of Real-Time PCR Assays for Quantification of erm Genes Conferring Resistance to Macrolides-Lincosamides-Streptogramin B in Livestock Manure and Manure Management Systems. Appl Environ Microbiol 2007, 73, (14), 4407-4416.

149. Yu, Z.; Michel, F. C., Jr.; Hansen, G.; Wittum, T.; Morrison, M., Development and application of real-time PCR assays for quantification of genes encoding tetracycline resistance. Appl Environ Microbiol 2005, 71, (11), 6926-33.

150. Dungan, R. S.; Klein, M.; Leytem, A. B., Quantification of bacterial indicators and zoonotic pathogens in dairy wastewater ponds. Appl Environ Microbiol 2012, 78, (22), 8089-95.

151. Sun, J.; Li, L.; Liu, B.; Xia, J.; Liao, X.; Liu, Y., Development of aminoglycoside and $\beta$-lactamase resistance in intestinal microbiota of swine treated with lincomycin, chlorotetracycline and amoxicillin. Front Microbiol 2014, 5.

152. Fouhy, F.; Ross, R. P.; Fitzgerald, G. F.; Stanton, C.; Cotter, P. D., A degenerate PCR-based strategy as a means of identifying homologues of aminoglycoside and beta-lactam resistance genes in the gut microbiota. Bmc Microbiol 2014, 14, 25.

153. Cattoir, V.; Poirel, L.; Rotimi, V.; Soussy, C. J.; Nordmann, P., Multiplex PCR for detection of plasmid-mediated quinolone resistance qnr genes in ESBL-producing enterobacterial isolates. $J$ Antimicrob Chemother 2007, 60, (2), 394-7.

154. Kim, H. B.; Park, C. H.; Kim, C. J.; Kim, E. C.; Jacoby, G. A.; Hooper, D. C., Prevalence of plasmid-mediated quinolone resistance determinants over a 9-year period. Antimicrob Agents Chemother 2009, 53, (2), 639-45.

155. Wu, N.; Qiao, M.; Zhang, B.; Cheng, W. D.; Zhu, Y. G., Abundance and diversity of tetracycline resistance genes in soils adjacent to representative swine feedlots in China. Environ Sci Technol 2010, $44,(18), 6933-9$.

156. Marti, R.; Scott, A.; Tien, Y. C.; Murray, R.; Sabourin, L.; Zhang, Y.; Topp, E., Impact of manure fertilization on the abundance of antibiotic-resistant bacteria and frequency of detection of antibiotic resistance genes in soil and on vegetables at harvest. Appl Environ Microbiol 2013, 79, (18), $5701-9$.

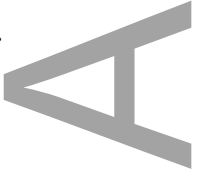

This article is protected by copyright. All rights reserved. 
157. Morrison, T.; Hurley, J.; Garcia, J.; Yoder, K.; Katz, A.; Roberts, D.; Cho, J.; Kanigan, T.; Ilyin, S. E.; Horowitz, D.; Dixon, J. M.; Brenan, C. J., Nanoliter high throughput quantitative PCR. Nucleic Acids Res 2006, 34, (18), e123.

158. Dixon, J. M.; Lubomirski, M.; Amaratunga, D.; Morrison, T. B.; Brenan, C. J.; Ilyin, S. E., Nanoliter high-throughput RT-qPCR: a statistical analysis and assessment. Biotechniques 2009, 46, (6), ii-viii.

159. Mayer-Blackwell, K.; Azizian, M. F.; Machak, C.; Vitale, E.; Carpani, G.; de Ferra, F.; Semprini, L.; Spormann, A.M., Nanoliter qPCR Platform for Highly Parallel, Quantitative Assessment of Reductive Dehalogenase Genes and Populations of Dehalogenating Microorganisms in Complex Environments. Environ Sci Technol 2014.

160. Gruzdev, N.; McClelland, M.; Porwollik, S.; Ofaim, S.; Pinto, R.; Saldinger-Sela, S., Global transcriptional analysis of dehydrated Salmonella enterica serovar Typhimurium. Appl Environ Microbiol 2012, 78, (22), 7866-75.

161. Stedtfeld, R. D.; Baushke, S. W.; Tourlousse, D. M.; Miller, S. M.; Stedtfeld, T. M.; Gulari, E.; Tiedje, J. M.; Hashsham, S. A., Development and experimental validation of a predictive threshold cycle equation for quantification of virulence and marker genes by high-throughput nanoliter-volume PCR on the OpenArray platform. Appl Environ Microbiol 2008, 74, (12), 3831-8.

162. Bugarel, M.; Beutin, L.; Scheutz, F.; Loukiadis, E.; Fach, P., Identification of genetic markers for differentiation of Shiga toxin-producing, enteropathogenic, and avirulent strains of Escherichia coli O26. Appl Environ Microbiol 2011, 77, (7), 2275-81.

163. Thaker, M.; Spanogiannopoulos, P.; Wright, G. D., The tetracycline resistome. Cell Mol Life Sci 2010, 67, (3), 419-31.

164. Karkman, A.; Johnson, T. A.; Lyra, C.; Stedtfeld, R. D.; Tamminen, M.; Tiedje, J. M.; Virta, M., High-throughput quantification of antibiotic resistance genes from an urban wastewater treatment plant. FEMS Microbiol Ecol 2016, 92, (3).

165. Xu, L.; Ouyang, W.; Qian, Y.; Su, C.; Su, J.; Chen, H., High-throughput profiling of antibiotic resistance genes in drinking water treatment plants and distribution systems. Environ Pollut 2016, $213,119-126$.

166. Wang, F. H.; Qiao, M.; Su, J. Q.; Chen, Z.; Zhou, X.; Zhu, Y. G., High throughput profiling of antibiotic resistance genes in urban park soils with reclaimed water irrigation. Environ Sci Technol 2014, 48, (16), 9079-85.

This article is protected by copyright. All rights reserved. 
167. Su, J. Q.; Wei, B.; Ou-Yang, W. Y.; Huang, F. Y.; Zhao, Y.; Xu, H. J.; Zhu, Y. G., Antibiotic Resistome and Its Association with Bacterial Communities during Sewage Sludge Composting. Environ Sci Technol 2015, 49, (12), 7356-63.

168. Ouyang, W. Y.; Huang, F. Y.; Zhao, Y.; Li, H.; Su, J. Q., Increased levels of antibiotic resistance in urban stream of Jiulongjiang River, China. Appl Microbiol Biotechnol 2015, 99, (13), 5697-5707.

169. Chen, Q.; An, X.; Li, H.; Su, J.; Ma, Y.; Zhu, Y.-G., Long-term field application of sewage sludge increases the abundance of antibiotic resistance genes in soil. Environ Int 2016, 92-93, 1-10.

170. Muziasari, W. I.; Parnanen, K.; Johnson, T. A.; Lyra, C.; Karkman, A.; Stedtfeld, R. D.;

Tamminen, M.; Tiedje, J. M.; Virta, M., Aquaculture changes the profile of antibiotic resistance and mobile genetic element associated genes in Baltic Sea sediments. FEMS Microbiol Ecol 2016, 92, (4).

171. Gawad, C.; Koh, W.; Quake, S. R., Single-cell genome sequencing: current state of the science. Nat Rev Genet 2016, 17, (3), 175-88.

172. Wang, X. R.; Kang, Y.; Luo, C. X.; Zhao, T.; Liu, L.; Jiang, X. D.; Fu, R. R.; An, S. C.; Chen, J. C.; Jiang, N.; Ren, L. F.; Wang, Q.; Baillie, J. K.; Gao, Z. C.; Yu, J., Heteroresistance at the Single-Cell Level: Adapting to Antibiotic Stress through a Population-Based Strategy and Growth-Controlled Interphenotypic Coordination. mBio 2014, 5, (1).

173. Moore, M. R.; Perdreau-Remington, F.; Chambers, H. F., Vancomycin treatment failure associated with heterogeneous vancomycin-intermediate Staphylococcus aureus in a patient with endocarditis and in the rabbit model of endocarditis. Antimicrobial Agents and Chemotherapy 2003, $47,(4), 1262-6$

174. Lasken, R. S., Genomic sequencing of uncultured microorganisms from single cells. Nat Rev Microbiol 2012, 10, (9), 631-40.

175. Martinez-Garcia, M.; Brazel, D. M.; Swan, B. K.; Arnosti, C.; Chain, P. S.; Reitenga, K. G.; Xie, G.; Poulton, N. J.; Lluesma Gomez, M.; Masland, D. E.; Thompson, B.; Bellows, W. K.; Ziervogel, K.; Lo, C. C.; Ahmed, S.; Gleasner, C. D.; Detter, C. J.; Stepanauskas, R., Capturing single cell genomes of active polysaccharide degraders: an unexpected contribution of Verrucomicrobia. Plos One 2012, 7, (4), e35314.

176. Grindberg, R. V.; Ishoey, T.; Brinza, D.; Esquenazi, E.; Coates, R. C.; Liu, W. T.; Gerwick, L.; Dorrestein, P. C.; Pevzner, P.; Lasken, R.; Gerwick, W. H., Single cell genome amplification accelerates identification of the apratoxin biosynthetic pathway from a complex microbial assemblage. Plos One 2011, 6, (4), e18565. 
177. Fleming, E. J.; Langdon, A. E.; Martinez-Garcia, M.; Stepanauskas, R.; Poulton, N. J.; Masland, E. D.; Emerson, D., What's new is old: resolving the identity of Leptothrix ochracea using single cell genomics, pyrosequencing and FISH. Plos One 2011, 6, (3), e17769.

178. Mason, O. U.; Hazen, T. C.; Borglin, S.; Chain, P. S.; Dubinsky, E. A.; Fortney, J. L.; Han, J.; Holman, H. Y.; Hultman, J.; Lamendella, R.; Mackelprang, R.; Malfatti, S.; Tom, L. M.; Tringe, S. G.; Woyke, T.; Zhou, J.; Rubin, E. M.; Jansson, J. K., Metagenome, metatranscriptome and single-cell sequencing reveal microbial response to Deepwater Horizon oil spill. ISME J 2012, 6, (9), 1715-27.

179. Zong, C.; Lu, S.; Chapman, A. R.; Xie, X. S., Genome-wide detection of single-nucleotide and copy-number variations of a single human cell. Science 2012, 338, (6114), 1622-6.

180. Gole, J.; Gore, A.; Richards, A.; Chiu, Y. J.; Fung, H. L.; Bushman, D.; Chiang, H. I.; Chun, J.; Lo, Y. H.; Zhang, K., Massively parallel polymerase cloning and genome sequencing of single cells using nanoliter microwells. Nat Biotechnol 2013, 31, (12), 1126-32.

181. Landry, Z. C.; Giovanonni, S. J.; Quake, S. R.; Blainey, P. C., Optofluidic cell selection from complex microbial communities for single-genome analysis. Methods Enzymol 2013, 531, 61-90.

182. Wang, Y.; Ji, Y. T.; Wharfe, E. S.; Meadows, R. S.; March, P.; Goodacre, R.; Xu, J.; Huang, W. E., Raman activated cell ejection for isolation of single cells. Anal Chem 2013, 85, (22), 10697-10701.

183. White, A. K.; VanInsberghe, M.; Petriv, O. I.; Hamidi, M.; Sikorski, D.; Marra, M. A.; Piret, J.; Aparicio, S.; Hansen, C. L., High-throughput microfluidic single-cell RT-qPCR. Proc Natl Acad Sci U S A 2011, 108, (34), 13999-4004.

184. Leung, K.; Zahn, H.; Leaver, T.; Konwar, K. M.; Hanson, N. W.; Page, A. P.; Lo, C. C.; Chain, P. S.; Hallam, S. J.; Hansen, C. L., A programmable droplet-based microfluidic device applied to multiparameter analysis of single microbes and microbial communities. Proc Natl Acad Sci U S A 2012, 109, (20), 7665-70.

185. Zhu, Z.; Zhang, W. H.; Leng, X. F.; Zhang, M. X.; Guan, Z. C.; Lu, J. Q.; Yang, C. J., Highly sensitive and quantitative detection of rare pathogens through agarose droplet microfluidic emulsion PCR at the single-cell level. Lab Chip 2012, 12, (20), 3907-3913.

186. Zhang, H. F.; Jenkins, G.; Zou, Y.; Zhu, Z.; Yang, C. J., Massively Parallel Single-Molecule and Single-Cell Emulsion Reverse Transcription Polymerase Chain Reaction Using Agarose Droplet Microfluidics. Anal Chem 2012, 84, (8), 3599-3606.

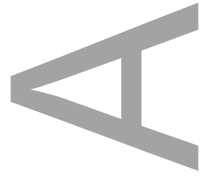

This article is protected by copyright. All rights reserved. 
187. Cai, D. Y.; Xiao, M.; Xu, P.; Xu, Y. C.; Du, W. B., An integrated microfluidic device utilizing dielectrophoresis and multiplex array PCR for point-of-care detection of pathogens. Lab Chip 2014, 14, (20), 3917-3924.

188. Rinke, C.; Lee, J.; Nath, N.; Goudeau, D.; Thompson, B.; Poulton, N.; Dmitrieff, E.; Malmstrom, R.; Stepanauskas, R.; Woyke, T., Obtaining genomes from uncultivated environmental microorganisms using FACS-based single-cell genomics. Nat Protoc 2014, 9, (5), 1038-48.

189. Navin, N.; Kendall, J.; Troge, J.; Andrews, P.; Rodgers, L.; McIndoo, J.; Cook, K.; Stepansky, A.; Levy, D.; Esposito, D.; Muthuswamy, L.; Krasnitz, A.; McCombie, W. R.; Hicks, J.; Wigler, M., Tumour evolution inferred by single-cell sequencing. Nature 2011, 472, (7341), 90-4.

190. Zhang, Q.; Zhang, P. R.; Gou, H. L.; Mou, C. B.; Huang, W. E.; Yang, M. L.; Xu, J.; Ma, B., Towards high-throughput microfluidic Raman-activated cell sorting. Analyst 2015, 140, (18), 6163-6174

191. Zhang, P. R.; Ren, L. H.; Zhang, X.; Shan, Y. F.; Wang, Y.; Ji, Y. T.; Yin, H. B.; Huang, W. E.; $\mathrm{Xu}$, J.; Ma, B., Raman-Activated Cell Sorting Based on Dielectrophoretic Single-Cell Trap and Release. Anal Chem 2015, 87, (4), 2282-2289.

192. Bengtsson-Palme, J.; Larsson, D. G. J., Antibiotic resistance genes in the environment: prioritizing risks. Nat Rev Micro 2015, 13, (6), 396-396.

193. Martinez, J. L.; Baquero, F., Mutation frequencies and antibiotic resistance. Antimicrob Agents Chemother 2000, 44, (7), 1771-7.

194. Klumper, U.; Droumpali, A.; Dechesne, A.; Smets, B. F., Novel assay to measure the plasmid mobilizing potential of mixed microbial communities. Front Microbiol 2014, 5, 730.

195. Jutkina, J.; Rutgersson, C.; Flach, C. F.; Joakim Larsson, D. G., An assay for determining minimal concentrations of antibiotics that drive horizontal transfer of resistance. Sci Total Environ 2016, 548-549, 131-138.

196. Liu, X.; Painter, R. E.; Enesa, K.; Holmes, D.; Whyte, G.; Garlisi, C. G.; Monsma, F. J.; Rehak, M.; Craig, F. F.; Smith, C. A., High-throughput screening of antibiotic-resistant bacteria in picodroplets. Lab Chip 2016, 16, (9), 1636-43.

197. Wang, Y.; Ran, M.; Wang, J.; Ouyang, Q.; Luo, C. X., Studies of Antibiotic Resistance of Beta-Lactamase Bacteria under Different Nutrition Limitations at the Single-Cell Level. Plos One 2015, 10, (5).

198. Maglica, Ž.; Özdemir, E.; McKinney, J. D., Single-Cell Tracking Reveals Antibiotic-Induced Changes in Mycobacterial Energy Metabolism. mBio 2015, 6, (1). 
199. Wang, Y.; Huang, W. E.; Cui, L.; Wagner, M., Single cell stable isotope probing in microbiology using Raman microspectroscopy. Curr Opin Biotech 2016, 41, 34-42.

200. Ledeboer, N. A.; Hodinka, R. L., Molecular Detection of Resistance Determinants. J Clin Microbiol 2011, 49, (9 Supplement), S20-S24.

\section{Figure legend}

Figure 1. Genomic technologies for studying ARGs in animals. Culture-based genomic and metagenomic methods have been commonly employed, and can be complemented by single-cell genomic methods to investigate the abundance and diversity of ARGs. Integration of these technologies will support modeling and prediction of the evolution, dynamics, and dissemination of ARGs within animals and further to environments and humans. Red dashed rectangles: metagenomics should be coupled with culture-based method for functional validation of annotated ARGs; culture-based genomic analysis would provide information for host identification of ARGs identified in metagenome. Green dashed rectangles, the compartmentalization of microbes in single-cell genomics would reduce the complexity of the microbial community, thus increasing the opportunity of obtaining complete genomes from the metagenome. Blue dashed rectangles: compartmentalization of microbes in single-cell genomics would enable growth optimization of various microbes without competition with other bacteria compared with a culture-based method.

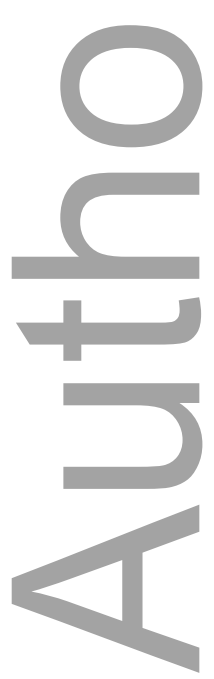




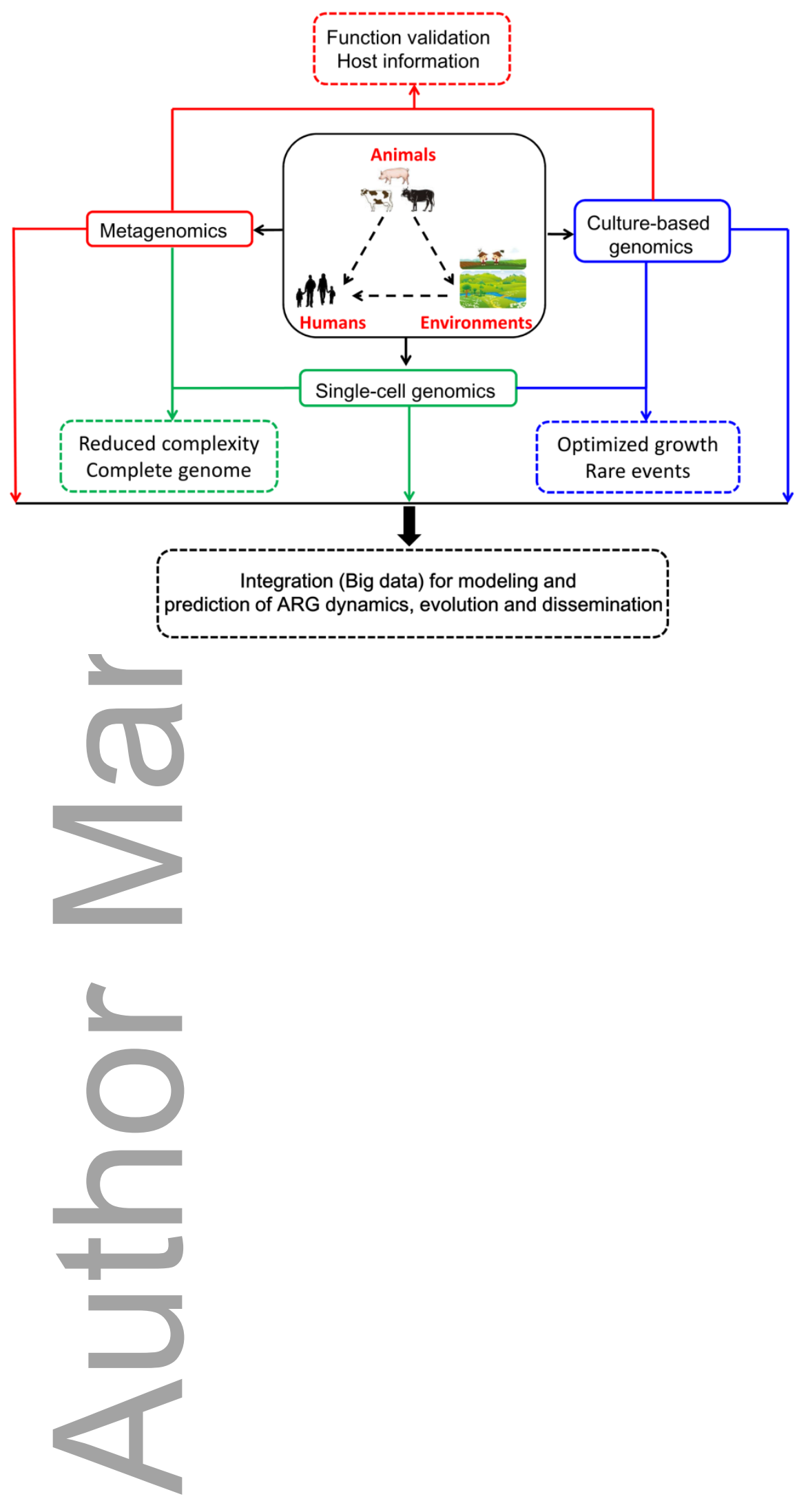

This article is protected by copyright. All rights reserved. 


\section{University Library}

\section{- M M N E R VA A gateway to Melbourne's research publications}

Minerva Access is the Institutional Repository of The University of Melbourne

Author/s:

Su, J-Q;Cui, L;Chen, Q-L;An, X-L;Zhu, Y-G

Title:

Application of genomic technologies to measure and monitor antibiotic resistance in animals

Date:

2017-01-01

Citation:

Su, J. -Q., Cui, L., Chen, Q. -L., An, X. -L. \& Zhu, Y. -G. (2017). Application of genomic technologies to measure and monitor antibiotic resistance in animals. ANNALS OF THE NEW YORK ACADEMY OF SCIENCES, 1388 (1), pp.121-135. https://doi.org/10.1111/ nyas. 13296.

Persistent Link:

http://hdl.handle.net/11343/292243 